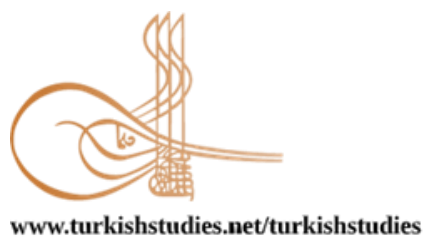

www.turkishstudies.net/turkishstudies
Turkish Studies

eISSN: $1308-2140$

Research Article / Araștırma Makalesi

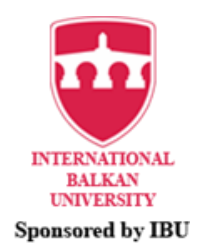

Sponsored by IBU

\title{
Davranışsal İktisatta Covid-19 Pandemi Süreci: Kaygı düzeyinin Sosyo-Ekonomik Karar Alma Davranışları Üzerine Etkisi
}

\author{
Covid-19 Pandemic Process in Behavioral Economics: The Impact of Anxiety Level on Socio- \\ Economic Decision-Making Behaviors
}

\author{
Büşra Ağan*
}

\begin{abstract}
In December in Wuhan city of China, which has become a global epidemic and the impact of the world's cases of coronavirus as many countries as in Turkey affected deeply in a view of socio-economic. As the pandemic process begins to spread massively, the tendency of individuals to over-interpret the danger and the social, economic and psychological risks created by global anxiety are gradually increasing. This study is based on the level of anxiety that can cause individuals to move away from rationality by rising risks and uncertainties. Social factors with their effects on society and family relations, psychological factors with their effects on individual mood, and economic factors with their effects on production-consumption habits and unemployment was evaluated of anxiety level with hypotheses. In this context, the aim of the study is to address the process in which psychological biases, systematic errors, and false deductions in individuals make decisions from rational behavior in unexpected situations such as epidemics. For this purpose, a questionnaire ${ }^{1}$ was prepared, presented to the participants on the internet in order to participate for more individuals, and the data of 550 individual participants were reached. The questionnaire data were analyzed and interpreted by using descriptive and correlational statistics technique. According to the results of the analysis, a significant relationship was found between anxiety levels of individuals and social, economic and psychological factors during this epidemic process. As a result, in the fight against epidemic as well as importance of physical examination that individual and community psychology are affected by uncertainty and misinformation due to anxiety, and this concern was replaced by serious socio-economic expectations at the end of the process.
\end{abstract}

Structured Abstract: Aim: The effects of the pandemic process of Covid-19 has become a global pandemic, which is being discussed positive and negative effects in Turkey. There is no doubt that the psychology created by outbreaks in the history of the world spreads much faster than the virus and affects even individuals who are not at risk of encountering the virus. Therefore, viral pandemic brings with it a pandemic psychology. The coronavirus outbreak significantly changes the lifestyle of millions of individuals in the worldwide and leaves lasting effects. During the spread of the outbreak; individuals, communities and governments prioritize to struggle, coordinated effort and shared values. It is expected that the economic, social and psychological dimensions of the pandemic process will be examined by using research techniques, and the obtained data will be evaluated with an analytical solutions and advices will be offered.

\footnotetext{
* Arş. Gör., Doğu Akdeniz Üniversitesi, İşletme ve Ekonomi Fakültesi, Ekonomi Bölümü. Res. Asst. Eastern Mediterranean University, Business and Economics Faculty, Economics Department. ORCID 0000-0003-1485-9142

busra.agan@emu.edu.tr
}

Cite as/ Atıf: Ağan, B. (2020). Davranışsal iktisatta Covid-19 pandemi süreci: kaygı düzeyinin sosyo-ekonomik karar alma davranışları üzerine etkisi. Turkish Studies, 15(6), 1001-1016. https://dx.doi.org/10.7827/TurkishStudies.43731

Received/Geliş: 21 May/Mayıs 2020

Accepted/Kabul: 15 October/Ekim 2020

Copyright $(\mathrm{C}$ MDE, Turkey 
In this study, firstly will focus on the effects of individual and society's anxiety level; then it will be discussed with its social, economic and psychological dimensions. The emergence of cognitive and emotional tendencies has played an important role in psychological research and social life. In this context, the aim of the study is how the individuals' knowledge and perceptions are managed in this epidemic process within the view of social, economic and psychological factors.

Material and Method: Studies have found that cognitive and emotional tendencies (such as framing, optimism, representativeness) have an impact on the diagnosis of neurological research (Tversky and Kahneman, 1974: 1124). A number of cognitive and emotional biases play an important role in the evaluation of individual decision-making behaviors based on behavioral economics. With this view, our aim is to predict possible socio-economic behavior of individuals.

For this purpose, the survey, conducted between April 15 and May 15, 2020, was presented to individuals on the internet for more individuals to participate, and data from 550 individual participants were reached. A total of 32 questions were included in the questionnaire. Some of these questions are personal information about participants, and some are questions to learn about the emotional and cognitive trends that are desired to be detected during the pandemic process. It also includes 5 Likert scale participation questions.

My research hypotheses are as in below:

H1: There is a relationship between anxiety level and social factors.

$\mathrm{H} 2$ : There is a relationship between anxiety level and economic factors.

H3: There is a relationship between anxiety level and psychological factors.

Findings: Three hypothesis created between anxiety level and social, economic, psychological tendencies. By testing with chi-squared test, a significant relationship was found between them at 5\% significance level. As a result of the findings obtained, it can be said that anxiety has an importance impact on social, economic and psychological factors.

As in below seen in Figure 1, the participants' opinions about unemployment after the epidemic process were asked. While $47 \%$ of the participants thought that there was a possibility of being unemployed after the Covid-19 epidemic process, $31 \%$ stated that they were not worried about the job and $22 \%$ were already unemployed. In addition, based on their answers obtained from the unemployment phenomenon in the main concerns of the economy, it was determined that most private sector employees were worried with the unemployment in this process.

Figure 1: Unemployment Anxiety

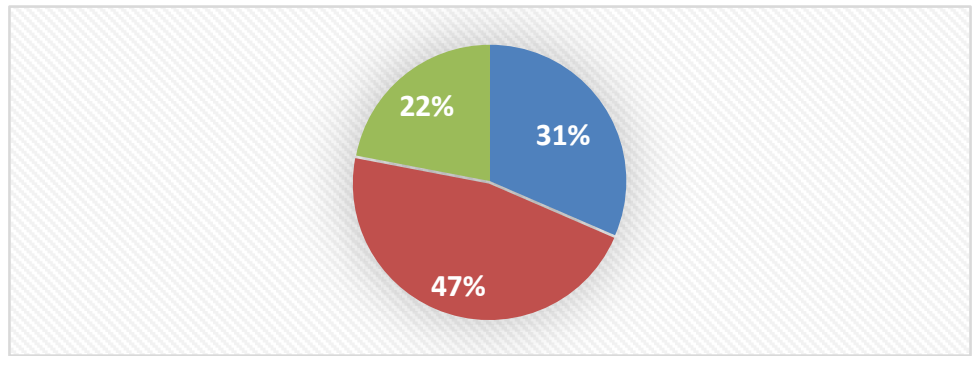

Source: Developed by the author

Conclusion: Countries all over the world have any differences like the demographic characteristics, lifestyles, value judgments, climate, commercial positions, production and consumption habits. This will cause similarities and differences on Covid-19 pandemic process. When individuals are under anxiety, they move away from the real causes and increase their sensitivity to what is happening around them. This process; showed that the importance of how current news is framed to their minds, they trust the current information and tend to compare with the information obtained from the past. Likewise, they have a big fear of cannot afford their basic needs after this pandemic process, they are afraid to be alone and lose their loved ones. In addition, regarding the economic factors, the effect of which is discussed to cause deep recession in all countries of the 
world; Individuals stated that there will be negative developments regarding the markets in the future and they have a fear of being unemployed at the end of this process.

After this pandemic process, it is thought that the economies will follow actions and policies towards selfsufficiency efforts. Sectoral priorities are expected to change, and existing policies will focus on domestic resources. For unemployment anxiety, individuals' income support suggestions and especially policies that will ensure the continuity of the current employment contracts of private sector employees will be beneficial. While my findings from the analysis emphasize that the importance of socio-economic cost perceived after the pandemic process, it suggests to societies a perspective that integrates a more collective behavioral decisionmaking model during this pandemic period.

Keywords: Covid-19, Coronavirus, Behavioral Economics, Cognitive and Emotional Tendencies, SocioEconomic Factors.

Öz: Çin'in Wuhan kentinde aralık ayında ortaya çıkan ve küresel bir salgın haline gelen koronavirüs vakaları dünyanın pek çok ülkesini etkilediği gibi Türkiye'yi de sosyo-ekonomik açıdan derin etkilemektedir. Pandemi süreci kitlesel olarak yayılmaya başladıkça bireylerin tehlikeyi aşırı yorumlama eğilimi ve küresel kaygının yarattığı sosyal, ekonomik ve psikolojik riskler giderek artmaktadır. Bu çalışmada risk ve belirsizliklerin artmasıyla bireylerin rasyonellikten uzaklaşmasına sebep olabilecek kaygı düzeyi temel alınmaktadır. Kaygı düzeyinin; toplum ve aile ilişkilerine etkisiyle sosyal faktörler, bireysel ruh hali üzerinde etkisiyle psikolojik faktörler ve üretim-tüketim alışkanlıkları ile işsizlik olgusu üzerindeki etkisiyle de ekonomik faktörler kurulan hipotezlerle değerlendirilmiştir. Bu kapsamda çalışmanın amacı salgın hastalık gibi beklenmedik durumlarda bireylerin sahip olduğu psikolojik önyargıların, sistematik hataların ve karar alma sürecinde yanlış çıkarımların bireyleri rasyonel davranışlardan alıkoyduğu süreci ele almaktadır. Bu amaçla anket ${ }^{2}$ formu hazırlanmış, daha fazla sayıda bireyin katılım sağlaması amacıyla internet ortamında katılımcılara sunulmuş ve 550 bireysel katılımcıya ait verilere ulaşılmıştır. Betimleyici ve korelasyonel istatistik tekniğiyle anket verileri analiz edilerek yorumlanmıştır. Analiz sonuçlarına göre salgın sürecinde bireylerin kaygı düzeyleri ile sosyal, ekonomik ve psikolojik faktörler arasında anlamlı ilişki bulunmuştur. Son olarak, salgınla mücadele de fiziki muayene kadar birey ve toplum psikolojisinin belirsizlik ve yanlış bilgilenmelerden kaynaklı kaygılardan etkilendiğini, süreç sonunda bu kaygı yerini önemli sosyo-ekonomik beklentilere bırakmıştır. İşletme ve Ekonomi Fakültesi Etik Alt Kurulu'nun 13.10.2020 tarih ve 2020/02 sayılı toplantısında incelenerek uygun bulunan, "Davranışsal İktisatta Covid-19 Pandemi Siireci: Kaygı Düzeyinin Sosyo-Ekonomik Karar Alma Davranışları Üzerine Etkisi" adlı dönem çalışmamız, Doğu Akdeniz Üniversitesi Bilimsel Araştırma ve Yayın Etiği Kurulu tarafindan onaylanmıştır.

Anahtar Kelimeler: Covid-19, Koronavirüs, Davranışsal İktisat, Bilişsel ve Duygusal Eğilimler, SosyoEkonomik Faktörler

\section{Giriş}

Küresel bir salgın haline gelen Covid-19 pandemi sürecinin etkileri Türkiye'de olumlu ve olumsuz hangi dönüşümleri gerçekleştireceği tartışılmaya başlanmaktadır. Pandemi sürecinin ekonomik, sosyal, psikolojik boyutları araştırma tekniklerinden yararlanılarak irdelenip, elde edilen veriler analitik bir anlayışla değerlendirilerek çözüm önerileri sunulması beklenmektedir. Çalışmada öncelikle bireysel ve toplumsal kaygı düzeyinin yaratacağı etkiler; sosyal, ekonomik ve psikolojik boyutlarıyla ele alınacaktır. Bilişsel ve duygusal eğilimlerin ortaya çıkması psikolojik araştırmalarda ve sosyal yaşamda önemli bir rol almıştır. Bireyler nesnel deneyime doğrudan yanıt vermezler; daha ziyade, davranışlarını uyaranların etkilesiyle yorumlama, anlaşılır hale getirme söz konusudur. Öyle ki; davranış, dünyanın gerçek durumlarına değil, gerçeklerin zihinsel temsillerine yöneliktir.

\footnotetext{
2 İşletme ve Ekonomi Faktültesi Etik Alt Kurulu'nun 13.10.2020 tarih ve 2020/02 sayılı toplantısında incelenerek uygun bulunan, "Davranışsal İktisatta Covid-19 Pandemi Siireci: Kaygı Düzeyinin Sosyo-Ekonomik Karar Alma Davranışları Üzerine Etkisi" adlı dönem çalışmamız, Doğu Akdeniz Üniversitesi Bilimsel Araştırma ve Yayın Etiği Kurulu tarafindan onaylanmıştır.
} 
Yapılan araştırmalarda, bilişsel ve duygusal önyargıların (çerçeveleme, iyimserlik, temsil edilebilirlik gibi) nörolojik araştırmaların tanısında etkileri olduğu bulgulanmıştır (Tversky ve Kahneman, 1974: 1124). Bu önyargılar, düşüncemizi etkileyen birkaç diğer faktör arasında yer almaktadır. Yanlış ayarlanmış içgüdüler, çevresel etkileşimler, yanılsamalar, geçmişe bağl1lıklar gibi bireysel önyargılar toplumun içinde bulunduğu koşullara bağlı olarak sosyal bir sonuca dönüşmektedir. Özellikle son zamanlarda yaşadığımız Koronavirüs salgını gibi toplumu ilgilendiren olağanüstü durumlar, bireysel sosyal ve ekonomik kararlarımızı etkilemede rol oynayan iki temel faktörü; bilişsel ve duygusal tepkileri açığa çıkarmaktadır. Bilişsel hatalar, bireylerin zihin ve zihinsel muhasebe hatalarına nasıl düştüklerini ve bu hataların nasıl sonuçlandıklarıyla ilgilenmektedir. Öyle ki; hatalı bir akıl yürütmenin sonucudur. Bu durumda yanlış bilgiler bireylerin etkisiz ilaçlara yönelmelerine ve mal ve hizmetleri istifleyerek aşırı tepki vermelerine veya riskli davranışlarda bulunarak daha tehlikeli bir şekilde düşük tepki göstermelerine neden olabilemektedir. Sonuç olarak, bireylerin virüsün yayılma hızının yanı sıra, ekonomik karar alma davranışlarında Covid-19 ile ilgili yanlış bilgilere hem inandıkları hem de bu bilgileri paylaşım yaptıkları, mevcut durumu olduğundan daha fazla abartma eğilimde bulunarak değerlendirdikleri bir irrasyonel süreç yaşanmıştır. Yaşanılan süreç Covid-19 gibi bulaşıcı hastalıkların kontrol altına alınması ve tedavisi büyük ölçüde bireysel karar alma davranışıyla bağlantılı olduğunu göstermektedir. Bireyler her zaman rasyonel olmamakla birlikte sistematik hatalar yaptıkları bir karar alma süreci yaşamaktadırlar. Koronavirus gibi salgınlara en etkili önlem, kaygının bireysel karar alma mekanizması üzerindeki etkisi de dahil olmak üzere bu tarz davranışsal eğilimleri dikkate almaktır. $\mathrm{Bu}$ amaçla daha iyi anlamak ve yanlış bilginin yayılmasını azaltmak için müdahaleler geliştirmek önemlidir.

Yüzyıllardır süregelen salgın hastalıklar ekonomiyi șekillenmiș ve etkileri tartıșılmıștır. Kara ölüm, veba, kolera, İspanyol gribi ve SARS'1 düşünürek, yeni koronavirüs (Covid-19) muhtemelen bu listeye eklenecek ve toplumları ve ekonomileri şekillendiren bir kavram olarak kollektif belleğimizin bir parçası haline gelecektir. Giderek artan önemi ve etkileri çerçevesiyle çalışmanın amacı, bireylerin sahip oldukları bilgi ve algının salgın sürecinde nasıl yönetildiklerini; sosyal, ekonomik ve psikolojik eğilimler çerçevesinde açıklayabilmektir. Bu amaçla, 15 Nisan- 15 Mayıs 2020 tarihleri arasında gerçekleştirilen anket çalışması, daha fazla sayıda bireyin katılım sağlaması amaciyla internet ortamında yatırımcılara sunulmuş ve 550 bireysel katılımcıya ait verilere ulaşılmıştır. Analizden elde edilen bulgular; bireylerin kaygı altındayken gerçek nedenlerden uzaklaşıp çevresinde olup bitene karşı duyarlılığını arttırdığı gözlenmiştir. Bu süreç; güncel haberlerin zihinlere nasıl çerçevelendiğinin önemini, mevcut bilgilere güvenip geçmişten elde edilen bilgilerle kıyaslama yaptıklarını, temel ihtiyaçlarını karşılayamama korkusu yaşadıklarını, yalnız kalmaktan ve sevdiklerini kaybetme korkusu içinde olduklarını göstermiş̧tir. Ayrıca, etkisinin tüm dünya ülkelerinde derin durgunluklara yol açacağ 1 tartışılan ekonomik faktörlere ilişkin; bireyler gelecekte piyasalarla ilgili olumsuz gelişmelerin olacağını, bu süreç sonunda işsiz kalma korkusu yaşadıklarını belirtmişlerdir. Son olarak, salgın sonrası algılanan sosyo-ekonomik maliyetin önemini vurgulanırken, toplumlara bu salgın döneminde daha kollektif bir davranışsal karar verme modelini entegre eden bir bakış açısı önerilmektedir.

\section{Literatürde Davranışsal İktisata ilişkin Bilişsel ve Duygusal Eğilimler}

Davranışsal iktisat, bireylerin en iyi seçimlerden ziyade yeterince iyi seçimler yaptığını varsaydığı sürece neoklasik iktisat teorisine bir alternatiftir. Bilişsel faktörler bireylerin bilgiyi organize etme ve kullanma şekliyle ilişkili iken, duygusal faktörler de bilginin kayıt halinde bireylerin duygusal yönüyle ilgilidir. Salgın hastalık gibi toplumun içinde bulunduğu olağanüstü dönemlerde alınacak ekonomik kararlar ve sosyal davranışlarda mevcut duygusal faktörlerin etkisi bulunmaktadır. Nörolojik araştırmalar, bireylerin duygusal durum yaratan beyin bölgelerinin risk, ödül ve ceza bilgilerini işlediğini, böylece kararların tahmin edilebilir yönde etkilediğini göstermektedir (Thaler ve Sunstein, 2008: 304). Heyecan gibi duygusal faktörler, bireyleri risk 
almaya ve böylece kararlarını değerlendirirken daha güvenli olmaya neden olmaktadır. Endişe, kaygı, korku gibi olumsuz duyguların ise ters etkisi bulunmaktadır. Bireyler mevcut tercihleri ile çelişen bilgileri yeniden değerlendirerek pozitif duygusal durumu koruyabilmek için inançlarını güncellenmektedir. İnançları güncelleme süreci, yerini bilgilerin mevcut inançlar ve tercihler ile uyumuna bağlıdır. Bireylerin inançları ile bilgisinin ve davranış kalıplarının uyuşmadığı duruma bilişsel çeliş̧i adı verilmektedir (Kıyılar, Akkaya, 2016:293). 2002 yılında psikolog Daniel Kahneman, psikolojik araştırmalardan iktisat bilimlerine, özellikle de bireylerin önyargısı ve belirsizlik altında karar verme ile ilgili öngörülerini entegre etmesiyle Nobel Ekonomi Bilimi Ödülü'ne layık görüldü.

Davranışsal iktisatta, bilişsel ve duygusal eğilimler ile önerilen uygulamalarını birbirine bağlayan kavramsal bir model olmamakla beraber, birtakım davranış modelleri tipik olarak psikoloji, sinirbilim ve mikroekonomi teorisinden öngörüleri bütünleştirmektedir. Bu modellerin ilgili karar süreçlerinde seçici, bağlamsal ve çevresel olasılıklardan sapmaları hesaba katmadan, sistematik hata yapma eğiliminde olmaları bilişsel eğilimleri üzerinde yeni araştırmaları açığa çıkarmışıtr. Literatürde bilişsel ve duygusal eğilimlere yönelik yapılan bir araştırma da (Ariely, 2008: 280), yaklaşık 600 kişinin ölümüyle sonuçlanacak bir salgın hastalıkla karşı karşıya olduklarını düşünmeleri istenmiştir. Bu salgınla mücadele etmek için iki grup katılımcıya ikişer seçenek verilmiştir. İlk gruba verilen seçenekler şunlardır:

- $\quad$ A programı uygulanırsa 200 kişinin hayatı kurtulacaktır. kurtulamayacaktır.

B programı uygulanırsa üçte bir ihtimalle herkes kurtulacak, üçte iki ihtimalle kimse

$\mathrm{Bu}$ gruptakilerin yüzde $75^{\prime}$ i A programının uygulanmasının doğru olacağını söylemiştir. İkinci gruba ise aşağıdaki seçenekler verilmiştir:

- C programı kabul edilirse 400 kişi ölecektir.

- $\quad$ D programı kabul edilirse üçte bir ihtimalle kimse ölmeyecek, üçte iki ihtimalle herkes ölecektir.

$\mathrm{Bu}$ gruptakilerin yüzde $75^{\prime} \mathrm{i} \mathrm{D}$ programını seçmiştir. Seçenekler incelendiğinde iki durum dikkat çekicidir. Her gruba verilen ilk seçenek (A ve C) garanti bir sonuç vermekte, ikinci seçenekte ise (B ve D) olası getirisi daha fazla olan ama riski faktörü taşıyan bir sonucu göstermektedir. Her iki gruba da aslında aynı seçenekler verilmiş (A ve $C$ programları ile B ve D programları aynı sonucu verecektir) ama bu seçenekler her gruba farklı bir vurguyla yani çerçeveyle ifade edilmiştir. Birincide vurgulanan "yaşam" bir başka ifadeyle "kazanma" odaklı iken, ikincide "ölüm" yani "kaybetme" odaklıdır. Bu durumda garanti sonuç kazanma odaklı ifade edilirse (200 kişinin hayatı kurtulacaktır) riskten kaçınma davranışı sergilenmekte, aynı garanti sonuç kaybetme odaklı ifade edilirse (400 kişi ölecektir) katılımcılar risk almaya daha eğilimli olmaktadır. Kahneman bireylerin risk hesaplarken "ölmek" ve "kurtulmak" kavramlarından etkilendiklerini göstermiştir. Dolayısıyla bireylerin tercihlerini, soruyu veya durumu ortaya koyma biçimiyle yönlendirmek mümkün olabilmektedir. Sonuçta kaybetme duygusu kazanma duygusundan daha ağır basmaktadır.

Bilişsel ve duygusal eğilimler, bireylerin sosyal yaşamda sergiledikleri irrasyonel hatalarını ekonomik karar alma davranışları üzerinde izler ve davranışsal iktisadı anlamanın önemli bir temelini oluşturmaktadır. En yaygın bilişsel ve duygusal eğilim türlerinden bazıları (Kahneman ve Tversky: 1979); doğrulama eğilimi, sezgisel farkındalık, kendisine hizmet eden önyargı, çerçevelem eğilimi, dikkat yanlılığı, aktör-gözlemci yanlılığı, çapalama yanlılığı, yanlış bilgi etkisi, iyimserlik etkisi, bandwagon etkisi bireylerin sıklıkla karşılaştığı önyargılardır.

Doğrulama eğilimi, bireylerin mevcut inançlarına uygun bilgileri ve uygun olmayan kanıtları desteklemektedir. Bu eğilim bilgi toplama şeklini etkiler, aynı zamanda bilgiyi yorumlama ve 
hatırlama şeklini de etkilemektedir. Örneğin, belirli bir konuyu destekleyen ya da buna karşı çıkan bireyler sadece onu desteklemek için bilgi aramakla kalmayacak, aynı zamanda mevcut fikirlerini destekleyecek şekilde yorumlama eğilimindedir (Zweig, 2011: 88). 1960'larda, bilişsel psikolog Peter Cathcart Wason (1960), Wason'ın kural keşif görevi olarak bilinen bir dizi deney gerçekleştirilmiştir. Bu deneyler de, bireylerin mevcut inançlarını doğrulayan bilgi arama eğilimi olduğunu göstermiştir. Ne yazık ki, bu tür önyargılar durumlara nesnel olarak bakmayı engelleyerek karar alma davranışlarımızı etkilemekte ve hatalı seçimlere yol açabilmektedir. Bu gibi hatalı seçimler toplumların içinde bulunduğu olağanüstü dönemlerde daha baskın açığa çıkmaktadır. Diğer bir eğilim; sezgisel farkındalık, karar alma davranışlarının bilinçsiz olarak gerçekleştirildiğini ve üzerinde düşünebiliyorsanız önemli olması varsayımıyla öne sürülmüştür (Kahneman ve Tversky, 1974). Daha kolay akla gelen şeyler (aşinalık eğilimi) ile, gerçek dünyanın çok daha yaygın ve daha doğru yansımaları olduğuna inanılmaktadır. Tversky ve Kahneman'ın açıkladığı gibi eylemde sezgisel kullanılabilirliğin en açı örneklerinden biri, hazır örneklerin etkisidir. Bu durum bireylerin akıllarına hızla gelen aşina oldukları bilgilere daha fazla değer verdiklerini göstermektedir. $\mathrm{Bu}$ bilgilere daha fazla güven eğilimi göstermek gelecekte benzer olayların abartma olasılığını da arttırmaktadır. Salgın hastalıklarla mücadele de, bireylerin tarih boyunca süregelen yaşanmışlıkları, duyumları veya araştırıp öğrendikleri bilgilere daha fazla itaat ettiklerini göstermektedir (McNally, 1994:13).

Literatürde sıkça değinilen diğer birtakım eğilimler de; kendine hizmet eden önyarg1, kötü olaylarla karşılaşıldığında dış güçleri suçlama ancak, iyi şeyler olduğunda ise kendine bağlama eğilimidir. Dikkat yanlılığı eğilimi ise, bazı noktalara daha fazla dikkat etme ve aynı anda diğerlerini görmezden gelme eğilimini içerir. Bu durum sadece çevrede algıladığımız şeyleri değil, algılarımıza dayanarak verdiğimiz ekonomik kararları da etkilemektedir. Televizyon haberleri içerisinde bazı başlıkları görmezden gelirken, dikkatimiz seçeneklerden sadece birkaçı üzerinde yoğunlaşmaktadır. Araştırmacılar duygusal durumların dikkat yanlılığını etkileyebileceğini bulgulamışlardır. Endişeli bireyler bir bilgi süreci sırasında daha erken dikkat etme eğilimindeyken, depresif bireyler genellikle uyaranlar uzun bir süre sunulduktan sonra dikkat çekmeye eğilimlidir (Weston, Hauck ve Amlot, 2018). Aktör- Gözlemci yanlılığ ise, sosyal psikolojide bir bireyin kendi eylemlerini dış nedenlere, diğer insanların davranışlarını iç nedenlere bağlamaya eğilimi ifade eder. Ayrıca, sonuçların olumsuz çerçevelendiği durumlarda daha belirgin açığa çıkma eğilimindedir. Örneğin, bir birey kendisinin olumsuz bir vaka yaşadığı aynı şekilde bu süreçten negatif etkilendiği bir durum ile ilgili bireyler genellikle durumu veya karşılaştıları koşulları suçlarlar. Ancak başka bir bireye olumsuz bir şey olduğunda ise, bireyler genellikle kişisel seçimleri, davranışları ve eylemleri için bireyi suçlama eğilimindedirler. Bir diğer eğilim Kahneman ve Tversky'nin çalışmalarında araştırdıkları; çapalama (demir atma) yanlılı̆̆ıdır. Bu kavram, öğrenilen ilk bilgiye daha fazla önem atfetme ve güvenme eğilimidir. Çokça karşılaşılan bir diğer eğilim ise; yanlış bilgi etkisidir. Bu eğilim, bireylerin herhangi bir olay hakkında çevrelerinden ve başkalarından duyduğu haberlerden, söylentilerden etkilenmesidir. Yanlış bilgi etkisiyle bireyler, mevcut olayları olduğundan farklı yorumlama ve anlamlandırma eğilimi gösterirler. Diğer bir davranışsal eğilim ise; iyimserlik etkisi, olumsuz olayları yaşama şansının daha düşük ve olumlu olayları yaşama şansının daha yüksek olduğuna dair yanlış bir inancı ifade etmektedir. Sürü eğilimi olarak bilinen "Bandwagon etkisi" ise bireylerin çevrelerindeki daha büyük bir grupların verdiği kararlardan etkilenerek sergiledikleri bilişsel önyargı ya da düşünme hatasıdır. Bilişsel önyargılar genellikle insanların daha hızlı düşünmesine ve akıl yürütmesine yardımcı olmak için tasarlanmıştır, ancak genellikle yanlış hesaplamalar ve hatalar ortaya çıkarırlar. Son olarak ele alınması yararlı olacak bir diğer eğilim ise; Dunning-Kruger etkisi (1999), cahillerin ve yeteneksizlerin eksiklikleri kendileriyle ilgili algılarındaki hatalardan; yüksek bilgi düzeyine sahip, yeteneklilerin ise diğer insanlarla ilgili algılarındaki hatalardan kaynaklanıldığını savunmaktadır. Çalışmalarında bir konu hakkında gerekli bilgisi yetersiz olan bireylerin kendilerine daha çok güven duyduğu gözlenmiştir. 
Kısaca değindiğimiz davranışsal iktisat temelinde birtakım bilişsel ve duygusal eğilimler bireysel karar alma davranışlarının değerlendirilmesinde önemli bir rol oynamaktadır. Bu açıdan Coivd-19 pandemi sürecini birtakım eğilimler ışığında bireylerin sosyo-ekonomik davranışlarını öngörebilme çabası çalışmanın özünü oluşturmaktadır.

\section{Salgın Hastalıkların Sosyo-Ekonomik Etkileri}

Dünya tarihinde görülen salgınların yaratmış olduğu psikoloji virüsten çok daha hızlı bir şekilde yayılmakta ve virüsle karşılaşma riski olmayan bireyleri dahi etkilemektedir. Öyle ki; viral pandemi bir pandemik psikolojiyi de beraberinde getirmektedir. Koronavirüs salgını dünya çapında milyonlarca bireyin yaşam biçimin önemli ölçüde değiştirmekte ve kalıcı etkiler bırakmaktadır. Dünya salgın hastalıklar ile 1347-1351 yılları arasında Avrupa'da büyük yıkıma neden olan Kara veba salgınıyla başlarken, aralık ayı sonlarında Çin'in Wuhan kentinde ortaya çıkan Covid-19 adıyla bilinen yeni tip koronavirüs ile karşı karşıya kalmıştır. Covid-19 ile mücadale sürecini dünya sağlık örgütü küresel bir salgın ilan etmiştir. Bu salgına karşı, bilimlerden katkı yapılmaya başlanmıştır. Öncellikle tıbbi bilimsel katkılar; virüsün özelliklerini anlama, etkili tedavi yöntemlerini belirleme, bir aşı geliştirme ve test etme ihtiyacını karşılamak için sağlanmıştır. Virüsün sağlık boyutu kadar psikolojik ve sosyo-ekonomik etkileride gündeme gelmekte ve etkisi hissedilmeye başlanmaktadır.

Sosyal ve davranış bilimleri, halk sağlığını optimize etmek için hükümet ile koordineli işleri yürütme, insan davranışına ilişkin sosyal motivasyonları sürdürme, kaygı, korku ve yalnızlığı yönetme, kültürel faktörleri belirleme gibi çabaları desteklemektedir. Bulaşıcı bir hastalığa yakalanma ile ilgili endişe, kaygı gibi huzursuzluk yaratacak duyguların ortaya çıkması bireylerin sosyo-ekonomik karar alma davranışlarını etkilemektedir. Bu süreçte bireylerin birbirleriyle iletişimi ve izlenimi önem taşımaktadır.

Halk sağlığı konusundaki endişeler ve birtakım önlemler daha belirgin olduğunda, bireyler başkalarının davranışlarını daha yargılayıcı hale getirmektedir (Weston, Hauck ve Amlot: 2018). Bu nedenle politika yapıcıların durumu iyileştirme adına samimi girişimleri, güven yaratabilecek bir ortam ve sık, şeffaf bir iletişimin sağlanması önem arz etmektedir. Günlük yaşantı içerisinde birinin olası ölümünü düşünmek varoluşsal bir kaygı yaratabilmektedir. Benzer şekilde, bir bireyin veya bir grubun ve yahut tüm insanlığın olası ölümünü düşünmek kollektif bir kaygı yaratmaktadır. Tüm bu duygusal eğilimleri bir pandemi varoluşu olarak algılayan bireyler, öngörülemez bir ortamda hissettikleri kaygı ile birlikte çevresinde olup bitene karşı bir mücadeleye başlamaktadır. $\mathrm{Bu}$ varoluşsal tehdidin yol açtığ sergiledikleri gözlenmiştir. Coivd-19 salgını sürecinde bu durumu gözlemlediğimiz en ilginç örneği; en başta tuvalet kağıtları ve çeşitli tıbbi ürünler olmak üzere gıda ürünlerine de talebin arttığının görülmesidir. Bu tür panik satın alma psikolojisi, bireylerde gereğinden fazla stoklama ve de çevresinde olup bitene karşı aşırı hassaslaşma eğilimini ortaya çıkarmaktadır. Bu durum gerçek ihtiyaç sahiplerini ihtiyaçlarına erişilemez bir hale getirmektedir. Örneğin; Covid-19'un ABD için varoluşsal bir tehdide neden olduğuna inanmaya yönelen Amerika vatandaşları fiziki bir muayeneden çok daha fazla klinik kaygı vakalarının olduğunu bildirmişlerdir. Bu nedenle kaygı gibi duygusal eğilimler hem sosyal hem de anti-sosyal davranışları etkilemekte ve bu durum irrasyonel bir davranış biçimini ortaya çıkarmaktadır.

Bireyler irrasyonel duygularla hatalı inançlar oluşturmaktadırlar. Çünkü akıl, virüsün toplumu ya da dünyayı nasıl etkilediğini değil, bireyleri nasıl etkilediği üzerine bilişsel zayıflıklara neden olmaktadır. Bireyler zihinsel muhasebelerini üstel değil doğrusal olarak yapmaktadırlar. Paul Graham çalışmasında; bireyler Çin dışında 13.000 Covid-19 vakası olduğunu söylediğinde ya da bu sayının her üç günde iki katına çıktığını söylediğinde şaşırmamaktadır. Ancak onlara büyüme bu hızda devam ederse, 3 haftada 1.7 milyon vaka olacağını söylediğinde ise şaşkına dönmektedirler. Bireyler ikinci veya üçüncü dereceden etkilere değil, birinci dereceden etkilere odaklanma eğilimindedir. Örneğin; araba kazası yapan bir birey, büyük olasılıkla ilk etapta harap olmuş 
arabasına (birinci dereceden etki) üzülecektir. Bunun yanı sıra her gün okuldan almak zorunda olduğu çocuklarını nasıl alacağına ya da daha yüksek sigorta primlerinin aylık bütçesini nasıl etkileyeceğine (ikinci ve üçüncü dereceden etkiler) odaklanmayı erteleyecektir. Öyle ki; ikinci ve üçüncü dereceden etkiler bireyin hayatı üzerinde hasarlı arabadan daha büyük bir etki yaratacaktır. Koronavirüs üzerinde analizlerin çoğu da birinci dereceden etkiler içermektedir. Bireyler genellikle kötü sonuçlara yol açan olayların beklenmedik ve nadir yönlerini daha detaylı düşünme eğilimdedir. Bireylerin sürü halinde hareket etmeleri herhangi bir bilgi olmamasına rağmen aynı yönde davranış göstermeleridir. Bu duruma sebep olabilecek bir faktör ise söylentilerdir. Söylenti (Noise); 1986 yılında Fisher Black tarafından kullanılmıştır. Söylenti, bireylerin gözlemlerini mükemmellikten uzaklaştıran bir olgudur. Öyle ki; söylenti bilginin karşıtıdır. Black, bireylerin derin bilgi sahibi olmadan irrasyonel hareket ettiklerini vurgulamıştır.

Salgın hastalıklar birtakım etnik önyargıları azaltmaya da yardımcı olmaktadır. Bireylerin "ben” olarak davranış eğilimi, pandemi döneminde bir işbirliği dayanışmasına dönüşmektedir. Öyle ki; bireyler sosyal bir varlık olarak birlikte yaşamakta, gruplar oluşturmakta ve sosyal etkileşim içinde bulunmaktadır. Gündeme ilişkin fikiriler de sosyal etkileşimden etkilenmektedir. Bireyler, aynı zamanda çıkan haberleri kendilerine göre yorumlamakta ve karar alma davranışı sergilemektedir. Bu süreçte daha yoğun bir algılama süreci çalışmaktadır. Bireyler aynı uyarı veya bilgiyi farklı algılayabilmektedir. Bu algı farklılığının nedenleri; sahip oldukları değer yargıları, amaç ve hedefleri, gereksinimleri, bulundukları kültürel ortam, hisleri, tecrübeleri hatta fiziksel özelliklerinden kaynaklanmaktadır. Belirsizlik altında ve öngörülemez bir dönemde bireylerin sahip oldukları algılar yerini kaygıya bırakmaktadır Ayrıca, bu dönemde bireylerin iyimserliği ile sosyoekonomik karar alma davranışı arasında da bir ilişki vardır. Bireyler genellikle olumlu sonuçlara odaklanmak yerine olumsuz sonuçlardan kaçınmaktadır. Bu noktada kayıptan kaçınma eğilimi gündeme gelmektedir. Bu eğilime göre, bir kararı değerlendirirken önceki sonuçlar sadece mevcut seçimin beklenen kaybına eklenmektedir. Dolayısıyla, önceki kaybın etkisi, mevcut seçimin kayıp ve kazanç olmasına bağlıdır. Belirsizlik içinde karar verme zorunluluğu bireylerde kaygı yaratır. Allen Whellis adlı bir psikoterapist bu durumu şöyle tanımlamaktadır: "Bazı insanlar bir kavşakta durur ve hiçbir yöne gidemez. Orada yeterince uzun oturursa sonunda yolların birleşeceğini ve isteklerinin oluşacağını düşünür." Bu benzetme karar verme güçlüğ̈̈ yaşayan bireylerin durumunu açıklamaktadır. Dolayısıyla bireylerin sahip oldukları kaygı düzeyi, belirsizlik ve öngörülemezliğin olduğu bir ortamda daha fazla beklenmedik sonuçlar yaratarak, rasyonel davranış kalıplarından uzaklaşmaya neden olmaktadır.

\section{Kaygı düzeyinin Sosyo-Ekonomik Karar Alma Davranışları Üzerine Etkisi: Anket Uygulaması}

Araştırmanın amacına, yöntemine, araştırma hipotezleri ile araştırma bulgularına yer verilecektir. Pandemi sürecinde kaygı düzeyinin sosyal ve ekonomik faktörlerle etkileşimine ek olarak psikolojik eğilim kaynaklılığı da araştırtırılacaktır.

\section{Araştırmanın Amacı ve Yöntemi}

$\mathrm{Bu}$ çalışmanın amacı bireylerin pandemi sürecinde yaşadıkları duygusal ve bilişsel süreci davranışal iktisat eğilimlerin çerçevesinde değerlendirmek ve kaygı düzeyi ile sosyal, ekonomik ve psikolojik faktörler arasında anlamlı bir ilişkinin varlığını sınamaktır. Bu amaçla davranışsal çeşitli eğilimlerin pandemi sürecinde bireyler üzerindeki etkisini analiz edebilmek için çalışmanın yazar tarafından bir anket formu hazırlanmıştır. ${ }^{3} 15$ Nisan- 15 Mayıs 2020 tarihleri arasında gerçekleştirilen anket çalışması, daha fazla sayıda bireyin katılım sağlaması amacıyla internet ortamında bireylere sunulmuş ve 550 bireysel katılımcıya ait verilere ulaşılmıştır. Anket formunda toplam 32 soru yer almıştır. Bu soruların bir kısmı katılımcılara ait kişisel bilgileri, diğer bir kısmı

\footnotetext{
${ }^{3}$ Talep edilmesi halinde anket formu paylaşılabilir.
} 
da pandemi sürecinde tespit edilmek istenilen duygusal ve bilişsel eğilimleri öğrenmeye yönelik sorulardır. Ayrıca 5'li Likert ölçekli katılım sorularını da içermektedir.

\section{Araştırma Hipotezi}

Kaygının sosyal, ekonomik ve psikolojik riskleri arttıracağı çalışmanın araşıtırma hipotezidir. Pandemi sürecinde küresel kaygıya ve bireylerin rasyonellikten uzaklaşmasına sebep olabilecek çeşitli psikolojik önyargılar söz konusudur.

\section{Anket Sonuçlarının Değerlendirilmesi}

Anket soruları soru tiplerine göre gruplanmış ve farklı tablolar yardımıyla sosyal, ekonomik ve psikolojik eğilimler araştırılmaya çalışılmıştır. Değerlendirme frekans ve yüzde (\%) dağılımları tablolaştırarak betimsel yorumlanmıştır. Anket verileri SPSS 20 istatistik paket programıyla analiz edilerek yorumlanmış ve hipotezlerin sonuçları değerlendirilmiştir.

Aşağıda belirtilen araştırma hipotezlerini test edebilmek üzere Ki-Kare test istatistiği kullanılmıştır.

H1: Kaygı düzeyi ile sosyal faktörler arasında ilișki vardır.

H2: Kaygı düzeyi ile ekonomik faktörler arasında ilişki vardır.

H3: Kaygı düzeyi ile psikolojik faktörler arasında ilişki varıdr.

\section{Analiz ve Sonuçları}

Katılımcıların demografik değişkenlerinin frekans ve nispi dağılımları aşağıdaki tabloda sunulmaktadır. Anket çalışmasından elde edilen verilerden 550 bireysel katılımcının demografik profili Tablo 1'de sunulmaktadır.

Tablo 1: Örneklemin Demografik Yapis1

\begin{tabular}{llcc}
\hline & & Frekans & Yüzdelik Pay (\%) \\
\hline Cinsiyet & Erkek & 328 & 59.63 \\
& Kadın & 222 & 40.36 \\
Yaş & 20 ve altı & 94 & 17.09 \\
& $21-25$ & 133 & 24.18 \\
& $26-30$ & 185 & 33.63 \\
\multirow{4}{*}{ Medeni Hal } & 138 & 25.09 \\
& 31 ve üstü & 222 & 40.36 \\
& Bekar & 291 & 52.91 \\
Eŭitim & Evli & 37 & 6.72 \\
Durumu & Boşanmış & & \\
& İlköğretim & 209 & 13.81 \\
& Ortaöğretim & 154 & 38 \\
& Üniversite & 111 & 28 \\
& Yüksek Lis/ & & 20.18 \\
\hline
\end{tabular}

Tablo 1'de kat1lımcıların \%59,6'si erkek, \%40,4'i kadındır. Örneklemin \%17,09'i 20 ve altı yaşları arasındayken, \%24,18'si 21-25 yaşları, \%33,63'i 26-30 yaşları ve \%25,09'i ise 31 ve üstü yaşları arasındadır. Ankette katılımcıların çoğunluğu orta yaş aralığındaki katılımcılardan 
oluşmaktadır. Ayrıca çalışmaya katılımcıların büyük bir çoğunlu başta Türkiye'nin üç büyük ili olmak üzere diğer illerden de katılımcılar mevcuttur.

\section{Sosyal, Ekonomik ve Psikolojik Eğilimlerin Değerlendirilmesi}

Bireysel katılımcıların pandemi sürecinde yaşanan sosyal, ekonomik ve psikolojik eğilimlerini belirlemek ve analiz etmek amacıyla 5'li Likert ölçeği yardımıyla sorular katılımcılara yöneltilmiş ve eğilimlerine ait önermeler değerlendirilmiştir. Önermeler katılım düzeyleri ile; kesinlikle katılıyorum (5), kat1lıyorum (4), kararsizım (3), katılmıyorum (2) ve kesinlikle katılmıyorum (1) şeklinde derecelendirilmiştir. Tüm önermeler için minimum değer (1), maksimum değer (5) olarak alınmıştır. Elde edilen verilerin nispi dağılımları grafikler halinde sunulmuştur.

Şekil 1: Sosyal Eğilimler

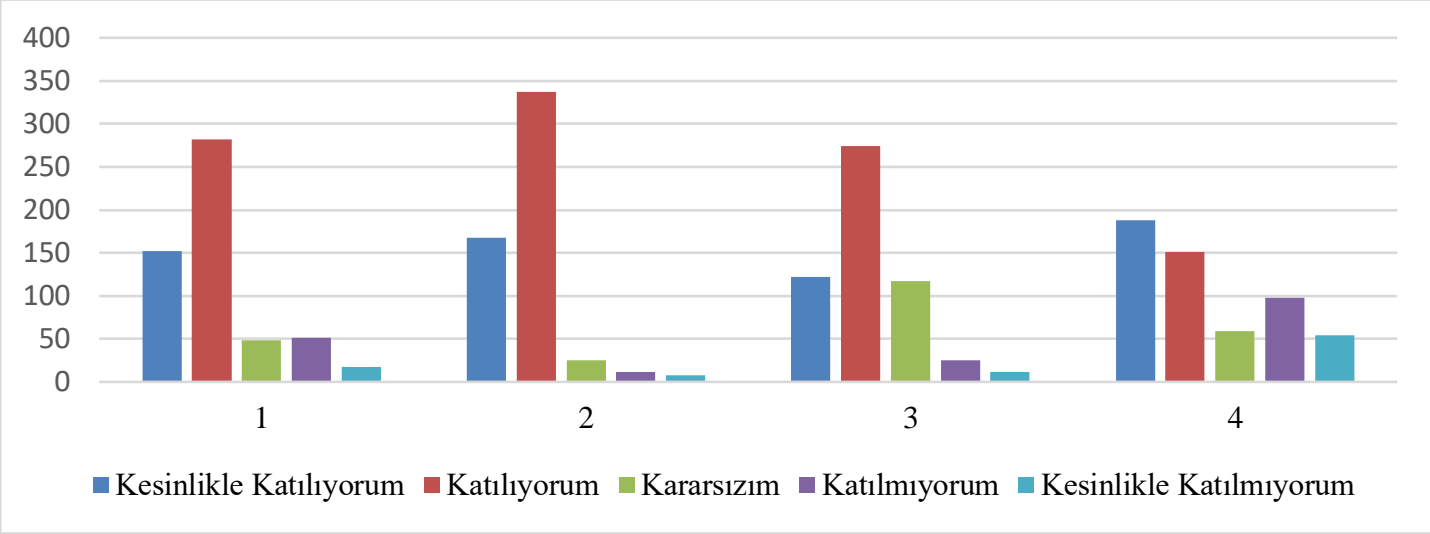

Kaynak: Yazar tarafindan geliştirilmiştir.

Şekil 1'de "Bu süreç içinde aile içi bağlarım güçlendi" önermesi 1'e; katılımcılarının \%79'u "katılıyorum/kesinlikle katılıyorum" cevabını işaretlerken, \%12'si "katılmıyorum/kesinlikle katılmıyorum" olarak seçimde bulunmuştur. \%9'u ise "kararsızım" yanıtını vermiştir. Katılımcıların büyük çoğunluğu aile içi ilişkilerin pandemi süreci içerisinde güçlendiğini söylemektedir.

"Ülkeler bu salgına birlikte ve bireyler danışma içinde çözüm aramalıdır” önermesi 2'de; katılımcılarının \%92'si "katılıyorum/kesinlikle katılıyorum" cevabını ișaretlerken, \%3'ü "katılmıyorum/kesinlikle katılmıyorum" olarak seçimde bulunmuştur. \%5'i ise "kararsızım" yanıtını vermiştir. Büyük oranda katılımcılar dayanışma ve işbirliğinin pandemi sürecinde olması gereken bir çözüm olarak düşünmektedir.

"Bu süreç sonunda normale dönmenin uzun zaman alacağına inanıyorum” önermesi 3'de; katılımcılarının \%72'si "katılıyorum/kesinlikle katılıyorum" cevabını işaretlerken, \%7'si "katılmıyorum/kesinlikle katılmıyorum" olarak seçimde bulunmuştur. \%21'i ise "kararsızım" yanıtını vermiştir. Elde edilen oranlardan anlaşıldığı üzere katılımcılar normalleşme sürecinin zaman alacağı bilincindedir.

“Günlük işlerimi yapma biçiminizde değişiklik oldu” önermesi 4'te; katılımcılarının \%61'i "katılıyorum/kesinlikle katılıyorum" cevabını işaretlerken, \%28'i "katılmıyorum/kesinlikle katılmıyorum" olarak seçimde bulunmuştur. \%11'i ise "kararsızım" yanıtını vermiștir. Katılımcıların büyük çoğunluğu günlük planlarında ve iş yapma akışında değişikliklerin olduğunu söylemektedir. 
Şekil 2: Psikolojik Eğilimler

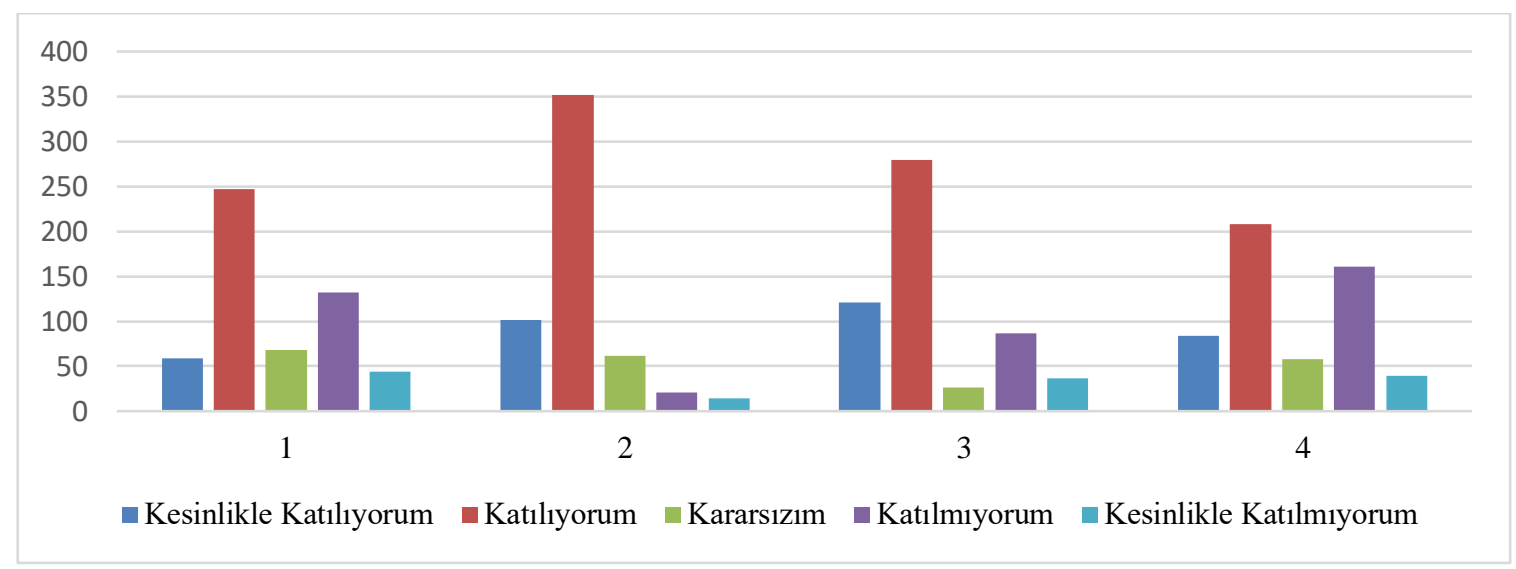

Kaynak: Yazar tarafindan geliştirilmiştir.

Şekil 2'de "Salgın sonrası, huzursuzluğum arttı ve kendimi yalnız hissediyorum" önermesi 1'e; katılımcılarının \%56'sı "katılıyorum/kesinlikle katılıyorum" cevabını işaretlerken, \%32'si "katılmıyorum/kesinlikle katılmıyorum" olarak seçimde bulunmuştur. \%12'si ise "kararsızım" yanıtını vermiştir. Katılımcıların büyük çoğunluğu salgının başlamasıyla kendilerini huzursuz ve yalnız hissettiklerini belirtmiştir.

“Sevdiklerimi kaybetmekten korkar hale geldim” önermesi 2'de; katılımc1larının \%82'si "katılıyorum/kesinlikle katılıyorum" cevabını işaretlerken, \%7'si "katılmıyorum/kesinlikle katılmıyorum" olarak seçimde bulunmuştur. \%11'i ise "kararsızım" yanıtını vermiştir. Büyük oranda katılımcilar sevdiklerini kaybetmekten korktuğunu ifade etmiştir.

"Salgınla mücadele de çevremdeki bireylerin endişe ve kaygılı tavırları beni de endișelendirir" önermesi 3'de; katılımcılarının \%73'ü "katılıyorum/kesinlikle katılıyorum" cevabını işaretlerken, \%23'ü "katılmıyorum/kesinlikle katılmıyorum" olarak seçimde bulunmuştur. \%5'i ise "kararsızım" yanıtını vermiştir. Elde edilen oranlardan anlaşıldığı üzere salgınla mücadele sürecinde katılımcıların etraflarındaki endişeli ve kaygılı yaklaşımlardan etkilendikleri görülmektedir. "Sürekli virüs kapma korkusu yaşıyorum" önermesi 4'te; katılımcılarının \%53'ü "katılıyorum/kesinlikle katılıyorum" cevabını işaretlerken, \%36's1 "katılmıorum/kesinlikle katılmıyorum" olarak seçimde bulunmuştur. \%11'i ise "kararsızım" yanıtını vermiştir. Katılımcıların \%50'si virüs kapma korkusu yaşadıklarını belirtmiştir.

Şekil 3: Ekonomik Eğilimler

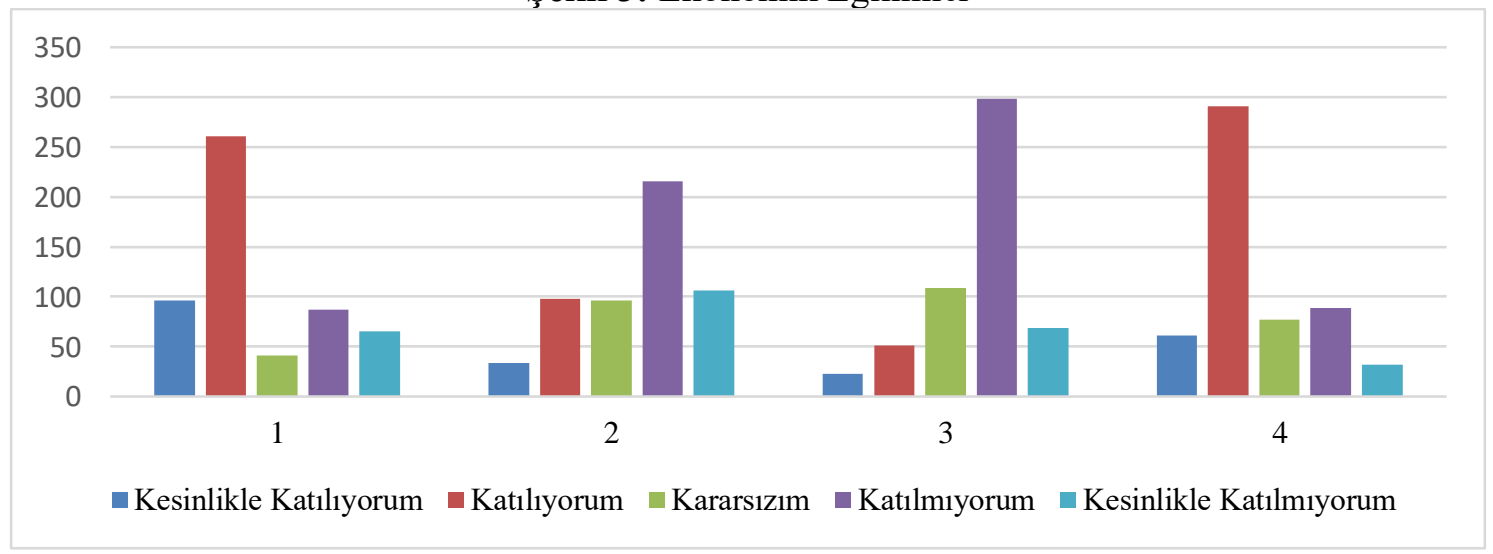

Kaynak: Yazar tarafindan geliştirilmiştir. 
Şekil 3'de "Covid-19 salgının ekonomik etkilerini değerlendirirken geçmişteki salgınlarla karşılaştıııım" önermesi 1'e; katılımcılarının \%65'i "katılıyorum/kesinlikle katılıyorum" cevabını işaretlerken, \%28'i "katılmıyorum/kesinlikle katılmıyorum" olarak seçimde bulunmuştur. \%7'si ise "kararsızım" yanıtını vermiştir. Katılımcıların büyük çoğunluğu yaşanılan Covid-19 pandemi sürecinin ekonomik etkilerini değerlendirirken geçmiş salgınlarla kıyaslama yaptıklarını belirtmektedir.

"Salgın süresince ekonomik duruma ilişkin mevcut ve geçmiş bilgilerden daha çok, elde ettiğim özel bilgilere göre hareket ederim." önermesi 2'de; katılımc1larının \%24'ü "kat1lıyorum/kesinlikle katılıyorum" cevabını işaretlerken, \%58'i "katılmıyorum/kesinlikle katılmıyorum" olarak seçimde bulunmuştur. \%18'i ise "kararsızım" yanıtını vermiştir. Büyük oranda katılımcılar ekonomik sürece ilişkin elde edilebilecek özel bilgilerden ziyade geçmiş ve mevcut bilgilere önem verdiğini, aşina olana eğilim gösterdiği görülmektedir.

"Gelecek dönemde yerel ve uluslararası piyasalarda meydana gelecek ekonomik gelişmelerin pozitif yönlü olacağını düşünüyorum" önermesi 3'de; katılımcılarının \%13'ü "katılıyorum/kesinlikle katılıyorum" cevabını işaretlerken, \%67'si "katılmıyorum/kesinlikle katılmıyorum" olarak seçimde bulunmuştur. \%20'si ise "kararsızım" yanıtını vermiştir. Elde edilen oranlardan anlaşıldığı üzere katılımcılar, salgınla mücadele süreci sonrasında yerel ve uluslararası piyasalarda gelişmelerin pozitif yönlü olacağını düşünmemektedir.

"Gelecekte aç kalma/temel ihtiyaçlarınızı karşılayamama korkusu yaşıyorum” önermesi 4'te; katılımcılarının \%64'ü "katılıyorum/kesinlikle katılıyorum" cevabını işaretlerken, \%22'si "katılmıyorum/ kesinlikle katılmıyorum" olarak seçimde bulunmuştur. \%14'ü ise "kararsızım" yanıtını vermiştir. Katılımcıların büyük çoğunluğu gelecekte temel ihtiyaçlarını karşılayamama kaygısı yaşamaktadır.

Şekil 4: İşsizlik Kaygısı

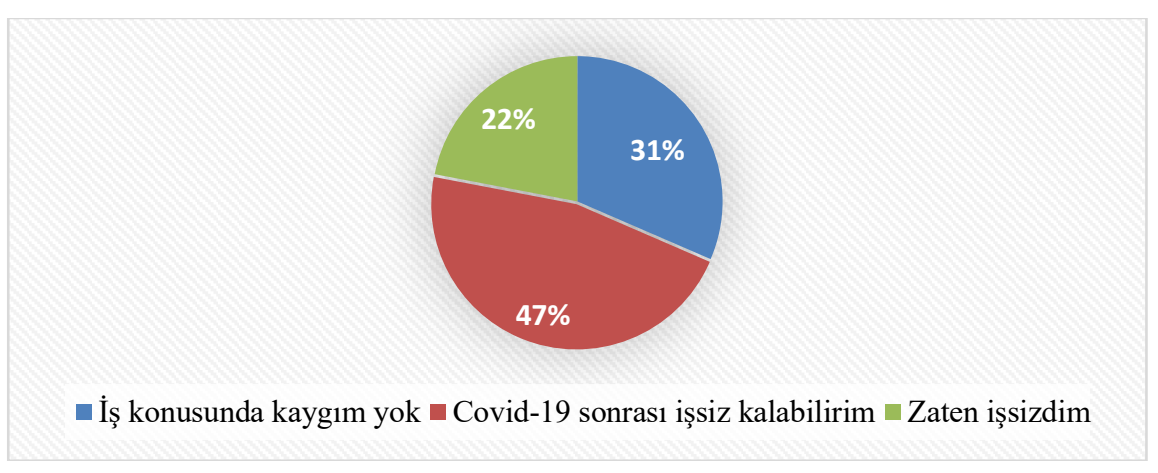

Kaynak: Yazar tarafindan geliştirilmiștir.

Şekil 4'de görüldüğü üzere salgın süreci sonrası işsizlik konusunda katılımcıların düşünceleri sorulmuştur. Katılımcıların \%47'sinin Covid-19 salgın süreci sonrasında işsiz kalma ihtimalinin olduğunu düşünürken, \%31'I iş konusunda kaygısının olmadığını, \%22'si ise zaten işsiz durumda olduğunu belirtmiştir. Ayrıca ekonomin temel sıkıntılarında işsizlik olgusu elde edilen yanıtlardan hareketle, pandemi süreci içerisinde en çok özel sektör çalışanlarının kaygısı olduğu tespit edilmiştir. 


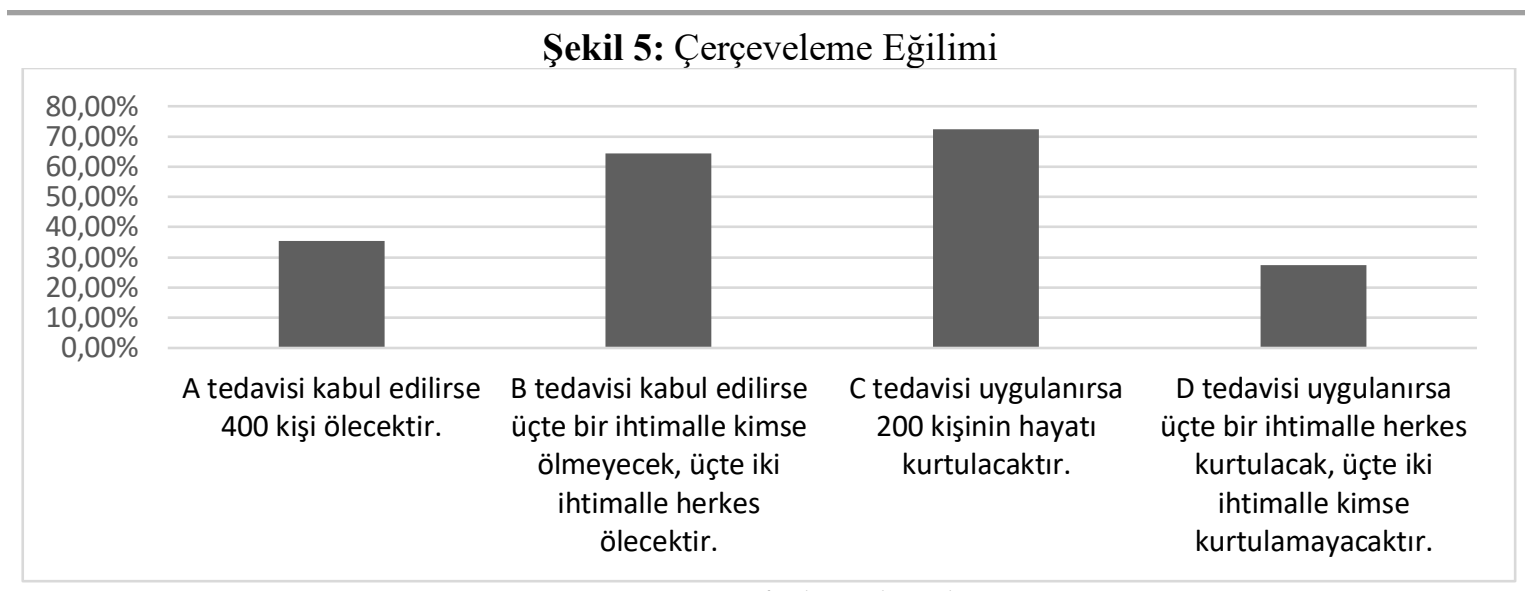

Kaynak: Yazar tarafindan geliştirilmiştir.

Şekil 5'te 600 bireyin ölümüyle sonuçlanacak bir salgın hastalığa karşı “Aşağıdaki seçenekler arasında seçim yapmanız gerekseydi hangisini seçerdiniz?" sorusuna bu salgınla mücadele edebilmek için iki ayrı seçenek sunulmuştur. Mücadelenin iki farklı sunuş biçimiyle yapılacak çerçeveleme eğilimi üzerine odaklanılmak istenmiştir.

İlk çerçevede; katılımcıların \%35.5'i A tedavisi ile 200 kişinin hayatının kurtulmasını, $\% 64.5$ 'i B tedavisi ile üçte bir ihtimalle herkesin kurtulmasını, üçte iki ihtimalle kimsenin kurtulamayacağ ihtimali seçmiştir.

İkinci çerçevede; \% 72.5 'i C tedavisi ile 400 kişinin öleceğini, \%27.5' i D tedavisi ile üçte bir ihtimalle kimsenin ölmeyeceğini, üçte iki ihtimalle herkesin öleceği ihtimali seçmiştir. Her iki seçeneğin nihai sonucu benzer olsa da, olayların sunuş şekli bireylerin seçeneklerini, karar alma davranışlarını etkilemiştir. Benzer sonuçlar farklı çerçeveleme ile sunularak bireylerin kaygı, endişe, kayıptan kaçınma, risk alma eğilimleri üzerinde karar alma davranışlarını ortaya koymaktadır.

\section{Araştırma Hipotezlerinin Değerlendirilmesi}

Pandemi sürecinde bireylerin sahip oldukları kaygı düzeyleri ile sosyal, ekonomik ve psikolojik eğilimler arasında araştırılmak istenen hipotezler kurulmuş ve eğilimler ile ilgili anket soruları seçilerek test edilmiştir. Bir bağımlı değişkenin diğer bir bağımsız değişkenlerle arasında kurulan hipotezleri test edebilmek üzere Ki-kare test istatistiğinden yararlanılmıştır. Değişkenler arasındaki ilişkinin anlamlı olup olmadığını test eden Ki-kare analiz yönteminde; bir çapraz tabloda yer alan değişkenler arasında gözlenen ilişkinin istatistiksel olarak anlamlı olup olmadığını test etmek amaçlanmıştır. Araştırılan hipotezlerden elde edilen sonuçlar tablolar yardımıyla gösterilmiştir.

Tablo 2: Kaygı düzeyi ile Sosyal Faktörler arasındaki ilişki

\begin{tabular}{lccll}
\hline \multicolumn{2}{c}{ Hipotez } & Test istatistiği & & Hipotez sonucu \\
\hline $\mathbf{H}_{\mathbf{0}}:$ Kayg1 düzeyi ile Sosyal & & & \\
Faktörler arasında ilişki yoktur. & $\mathbf{X}^{2}=6,456$ & $\checkmark$ & Prob $<\alpha$ \\
$\mathbf{H}_{\mathbf{1}}$ : Kaygı düzeyi ile Sosyal & Prob=0,015 & $\checkmark$ & $\mathrm{H}_{0}$ hipotezi Reddedilir. \\
Faktörler arasında ilişki vardır. & & &
\end{tabular}

*Not: \%5 anlamlılık düzeyinde bakılmıştır.

Tablo 2'de katılımcıların salgın sürecinde kaygı düzeyleri ile sosyal faktörler arasındaki ilişki Ki-kare test istatistiği yönetimi ile araştırılmıştır. Ho hipotezinin reddedilmesiyle katılımcıların kaygı düzeyleri ile sosyal faktörler arasında \%5 önem seviyesinde anlamlı bir ilişki olduğu sonucuna 
ulaşılmaktadır. Bireylerin bu süreç içerisindeki endişeli ve kaygılı durumlarının sosyal faktörler üzerinde bir etkisinin ve anlamlı bir değişiminin olduğu gözlenmiştir.

Tablo 3: Kaygı düzeyi ile Ekonomik Faktörler arasındaki ilişki

\begin{tabular}{lcll}
\hline \multicolumn{1}{c}{ Hipotez } & Test istatistiği & & Hipotez sonucu \\
\hline $\mathbf{H}_{\mathbf{0}}$ : Kaygı düzeyi ile Ekonomik & & & \\
Faktörler arasında iliş̧ki yoktur. & $\mathbf{X}^{2}=9,848$ & $\checkmark \quad$ Prob $<\alpha$ \\
$\mathbf{H}_{\mathbf{1}}$ : Kayg1 düzeyi ile Ekonomik & $\mathbf{P r o b}=0,003$ & $\checkmark \quad \mathrm{H}_{0}$ hipotezi Reddedilir. \\
Faktörler arasında ilişki vardır. & & & \\
\hline
\end{tabular}

*Not: \%5 anlamlılık düzeyinde bakılmıştır.

Tablo 3'te katılımcıların salgın sürecinde kaygı düzeyleri ile ekonomik faktörler arasındaki ilişki Ki-kare test istatistiği yönetimiyle araştırılmıştır. Ho hipotezinin reddedilmesiyle katılımcıların kayg1 düzeyleri ile ekonomik faktörler arasında \%5 önem seviyesinde anlamlı bir ilişki olduğu sonucuna ulaşılmaktadır. Bireylerin bu süreç içerisindeki endişeli ve kaygılı durumlarının temel ekonomik faktörler üzerinde bir etkisinin ve bir anlamlı değişiminin olduğu gözlenmiştir.

Tablo 4: Kaygı̈ düzeyi ile Psikolojik Faktörler arasındaki ilişki

\begin{tabular}{lccl}
\hline \multicolumn{1}{c}{ Hipotez } & Test istatistiği & & Hipotez sonucu \\
\hline H $_{\mathbf{0}}$ Kayg1 düzeyi ile Psikolojik & $\mathbf{X}^{2}=7,476$ & $\checkmark$ & Prob $<\alpha$ \\
Faktörler arasında ilişki yoktur. & & & \\
H: Kayg1 düzeyi ile Psikolojik & Prob=0,007 & $\checkmark \quad \mathrm{H}_{0}$ hipotezi Reddedilir. \\
Faktörler arasında ilişki vardır. & &
\end{tabular}

*Not: \%5 anlamlılık düzeyinde bakılmıştır.

Tablo 4'te katılımcıların salgın sürecinde kaygı düzeyleri ile psikolojik faktörler arasındaki ilişki Ki-kare test istatistiği yönetimi ile araştırılmışıır. Ho hipotezinin reddedilmesiyle katılımcıların kayg1 düzeyleri ile psikolojik faktörler arasında \%5 önem seviyesinde anlamlı bir ilișki olduğu sonucuna ulaşılmaktadır. Bireylerin bu süreç içerisindeki endișeli ve kaygılı durumlarının doğrudan birtakım psikolojik faktörler üzerinde bir etkisinin ve anlamlı bir değişiminin olduğu gözlenmiştir.

Kaygı düzeyinin üç ayrı faktör ile ilişkisini kurduğum hipotezlerin test edilmesiyle aralarında \%5 önem seviyesinde anlamlı bir ilişki bulunmuştur. Elde edilen bulgular neticesinde kaygının sosyal, ekonomik ve psikolojik faktörler üzerinde etkili olduğu söylenebilmektedir.

\section{Sonuç ve Değerlendirmeler}

Covid-19 salgının yaşandığı tüm ülkelerin demografik özellikleri, yaşayış biçimleri, değer yargıları, iklimi, ticari konumları, üretim ve tüketim alışkanlıkları bu süreci etkileyen ve bu süreçten etkilenen temel faktörlerdir. Salgının yayılmasına yönelik; bireyler, topluluklar ve hükümetler mücadeleye, koordineli çabaya ve paylașılan değerlere öncelik vermektedir. Bu süreçle mücadele sürecinde başlayan ve devam etmesi beklenen birtakım sosyal, psikolojik ve ekonomik faktörlerin etkisi görülmeye başlanmıştır. Dolayısıyla bu dönemler de salgını bitirmeye yönelik sağlık sektöründe verilen mücadele gibi bireylerin kollektif bir etkileşim içinde oldukları görülmektir. Öyle ki; bireylerin her ne kadar korku ve endişeleri kendi benliğine bağllyken diğer tepki, korku ve endişeleri diğer bireylerin nasıl düşündüklerine ve nasıl tepki verdiklerine de bağlanmaktadır. Nöroekonomik araştımalar, duygusal durum yaratan beyin bölgelerinde risk, ödül ve ceza bilgilerini tahmin edilebilir yönde etkilediğini göstermektedir. Heyecan, kaygı gibi duygusal durumlar 
bireylerin karar alma davranışını etkilemektedir. Sonuç olarak; yapılan araştırmalarda heyecan bireyleri daha fazla risk almaya yönetirken, kaygı ise tam tersi etkileşim yarattığı görülmektedir.

Çalışmada, salgının yayılması kadar hızla yayılım gösteren kaygı düzeyinin sosyal, ekonomik ve psikolojik faktörlerle ilişkili olduğu bulgulanmıştır. Öyle ki; bireylerin kayg1 altındayken gerçek nedenlerden uzaklaşıp çevresinde olup bitene karşı duyarlılığ 1 artmaktadır. Bu süreç; güncel haberlerin zihinlere nasıl çerçevelendiğinin önemini, mevcut bilgilere güvenip geçmişten elde edilen bilgilerle kıyaslama yaptıklarını, temel ihtiyaçlarını karşılayamama korkusu yaşadıklarını, yalnız kalmaktan ve sevdiklerini kaybetme korkusu içinde olduklarını göstermiştir. Ayrıca, etkisinin tüm dünya ülkelerinde derin durgunluklara yol açacağı tartışılan ekonomik faktörlere ilişkin; bireyler gelecekte piyasalarla ilgili olumsuz gelişmelerin olacağını, bu süreç sonunda işsiz kalma korkusu yaşadıklarını belirtmişlerdir. $\mathrm{Bu}$ durum özellikle; özel sektör çalışanlarının bir süre işyerlerinin kapanması, üretimin kısıtlanması nedeniyle düzenli gelir akışı elde edememe ve süreç sonunda işsiz kalma korkusu beklentisini açığa çıkarmıştır. Mevcut birikimlerinin en çok birkaç ay veya bir yıl yeterli olabileceğini düşünmektedirler. Buna karşın kamu çalışanları işsiz kalma korkusu yaşamadıklarını ve bu dönem içerisindeki harcamaları azaldığı için daha fazla tasarruf edebildiklerini belirtmektedir. Öyle ki; pandemi sürecinde yaşanan durgunluk çeşitli sektörlerdeki kaynak yetersizliği yaratarak işsizlik oranlarını olumsuz etkilemektedir. Ayrıca, sosyal etkileşim içerisinde olan bireyler, bu süreçte gündelik alışkanlıklarının değiştiğini, bu sürecin aile içi dayanışmayı arttığını ve toplumların el birliği ve dayanışma ile bu salgının üstesinden gelebileceğini düşünmektedir.

Salgın sürecinin bireyler üzerinde yaratacağı etkilerden, analizde ele alınan yaklaşım ve eğilimlerle; bireyler ve toplumlar arasındaki etkileşim her ne kadar güçlü ise, şüphesiz ki dünya ekonomileri arasında etkileşim de bir o kadar güçlü etkiler yaratacaktır. Öyle ki; pandemi süreci sonrasında ekonomilerin yerelde kendine yetebilme çabalarına yönelik eylem ve politikalar izleyeceği düşünülmektedir. Sektörel önceliklerin değişmesi ve mevcut politikaların dışardan gelen kaynaktan ziyade içeride üretilebilecek kaynaklara yönelmesi beklenmektedir. Bireylerin işsizlik kaygısına gelir desteği önerileri ve özellikle özel sektör çalışanlarının mevcut iş sözleşmelerinin devamlılığını sağlayacak politikalar faydalı olacaktır. Ani ve beklenmedik durumlarda ekonomileri krizden kurtarabilecek dış talebi iç talebe yöneltecek tasarruf modellerinin geliştirilmesinin yine faydalı olacağı muhtemeldir. Ekonomi politikaların yönlendirilmesi ve geliştirilmesi sürecinde Koronavirüs gibi salgınlara en etkili yanıt, kaygının bireysel karar verme üzerindeki etkisi de dahil olmak üzere birtakım davranışsal eğilimlerin dikkate alınmasıdır. Son olarak, Lev Nikolayeviç Tolstoy'un "insana neye ihtiyacı olduğunu bilme yetisi verilmemişti. Zengin adamında neye ihtiyacı olduğundan haberi yoktu. Hiç kimse akşama çizmeye mi yoksa ölü terliğine mi ihtiyacı olacağın bilemez" sözleri pandemi sürecinde yaşanan kaygı düzeyinin sosyo-ekonomik karar alma davranışlarına etkisini anlamamıza yardımcı olacaktır.

\section{Kaynakça}

Ariely, D., Klaus W. (2002). Procrastination, Deadlines, and Performance: Self-Control by Precommitment, Psychological Science, 13 (3), 219-24.

Ariely, D. (2008). Predictably Irrational: The Hidden Forces That Shape Our Decisions. New York: Harper Collins, 280.

Black, F. (1986). Noise. Journal of Finance 41, 529-543.

Hough, D. (2013). Irrationality in Health Care: What Behavioral Economics Reveals About What We Do and Why, Vol. 342, No. 6155: 196. 
Kahneman, D., Tversky, A. (1979). Prospect Theory: An Analysis of Decision Under Risk. Econometrica, 47 (2), 263-291.

Kılıç, S. (2016). Cronbach'ın Alfa Güvenirlik Katsayısı. Gülhane Askeri Tıp Fakültesi, Ankara.

Kıyılar, M., Akkaya, M. (2016). Davranışsal Finans. Literatür.

Kruger, J., Dunning, D. (1999). Unskilled and unaware of it: How difficulties in recognizing one's own incompetence lead to inflated self-assessments. Journal of Personality and Social Psychology, 77(6), 1121-1134.

McNally, R. (1994). Cognitive Bias in Panic Disorder. Current Directions in Psychological Science, Vol. 3, No. 4,129-132.

Schaller, M. \& Duncan, L. A. (2007).The behavioral immune system: Its evolution and social psychological implications in Evolution and the social mind: Evolutionary psychology and social cognition 293-307 (Routledge/Taylor \& Francis Group)

Thaler, R. H., Sunstein. C. (2008). Nudge: Improving Decisions About Health, Wealth, and Happiness. New Haven: Yale University Press, 304.

Tolstoy, L. (1885). Insan Ne ile Yaşar. Kültür Yayınları.

Tversky, A., Kahneman, D. (1974). Judgment under Uncertainty: Heuristics and Biases. Science, New Series, 185(4157), 1124-1131.

Wason, P.C. (1960). On the failure to eliminate hypotheses in a conceptual task. Q. J. Exp. Psychol. $12,129-140$

Weston, D., Hauck, K., Amlot, R. (2018). Infection prevention behaviour and infectious disease modelling: a review of the literature and recommendations for the future. Research article.BMC Public Health, 18: 336.

Zhou, F. (2020). Clinical course and risk factors for mortality of adult inpatients with COVID-19 in Wuhan, China: a retrospective cohort study. The Lancet.

Zweig, J. (2011). Paranız ve Beyniniz. Çev.Necdet Ünal Elbeyli. İnkılap Kitabevi 